ZałącZnIil

\title{
STRATEGIE (NIE)INSTYTUCJI KULTURY. STUDIUM PRZYPADKU ZAMKU CIESZYN
}

\section{PATRYK DZIURSKI}

\begin{abstract}
Kolegium Zarządzania i Finansów, Szkoła Główna Handlowa w Warszawie

Collegium of Management and Finance, SGH Warsaw School of Economics pd54550@sgh.waw.pl
\end{abstract}

\section{WPROWADZENIE}

Strategie organizacji sektorów kultury są mało eksploatowanym tematem rozważań naukowych, ale liczba publikacji na ten temat stale wzrasta. Związane jest to zapewne ze wzrostem znaczenia sektorów kultury, a szerzej - także sektorów kreatywnych, w gospodarce oraz społeczeństwie. W naukach społecznych kultura oraz kreatywność postrzegane są coraz częściej jako trzon współczesnego rozwoju. Temat strategii w tychże sektorach jest szczególnie interesujący, gdyż organizacje w nich działające różnią się od przedsiębiorstw ${ }^{1}$. Powoduje to, że wszelkie badania, zarówno teoretyczne, jak i empiryczne, są niezwykle potrzebne, ponieważ pozwalają lepiej poznać specyfikę zarządzania organizacjami z sektorów kultury i kreatywnych, a przez to uchwycić pełen obraz obszaru badawczego. Celem niniejszego artykułu jest więc charakterystyka strategii organizacji z sektorów kultury na przykładzie (nie)instytucji kultury - Zamku Cieszyn, który łączy w sobie najlepsze elementy organizacji niedziałających dla zysku z elementami tych, które nastawione są na zysk. Studium przypadku poprzedza opis strategii organizacji oraz charakterystyka strategii organizacji w sektorach kultury.

Artykuł ma charakter teoretyczno-empiryczny. Na podstawie krytycznej analizy literatury rozwijam oraz uzupełniam propozycje teoretyczne, które następnie weryfikuję w studium przypadku. Narzędziami wykorzystanymi

1 Przedsiębiorstwo, czyli zorganizowany zespół składników niematerialnych i materialnych przeznaczonych do prowadzenia działalności gospodarczej. 
w opracowaniu studium przypadku są: wywiad pogłębiony częściowo ustrukturyzowany, analiza materiałów udostępnionych przez badaną organizację oraz informacji ogólnodostępnych.

\section{STRATEGIE ORGANIZACJI - WPROWADZENIE}

Strategia to bodajże najczęściej używane pojęcie w kontekście zarządzania organizacjami. Przyjmuje się, że realizacja celów oraz rozwój organizacji są utrudnione bez dobrze opracowanej strategii. W literaturze przedmiotu trudno jednak znaleźć jednoznaczną odpowiedź na pytanie, czym jest strategia. Krzysztof Obłój pisze, że „teoria strategii jest niczym dywan utkany z momentami przeciwstawnych - a w pewnych aspektach komplementarnych - głównych koncepcji”", do których można zaliczyć: teorię planistyczną, ewolucyjną, pozycyjną i zasobową ${ }^{3}$.

Planistyczna teoria strategii zakłada, że kadra menedżerska jest władna w swobodny i racjonalny sposób kształtować plan strategiczny ${ }^{4}$. Strategię rozumie się więc jako zbiór decyzji planistycznych, podejmowanych w oparciu o szczegółową analizę otoczenia organizacji oraz jej mocnych i słabych stron (klasycznym narzędziem teorii planistycznej jest analiza SWOT ${ }^{5}$ ), które to decyzje mają zapewnić osiągnięcie przyjętych celów ${ }^{6}$. W opozycji do teorii planistycznej powstała teoria ewolucyjna. Przyjmuje się w niej, że tworzenie strategii jest niesformalizowanym procesem poszukiwania

2 K. Obłój, Strategia organizacji, wyd. III, Warszawa 2014, s. 24.

3 Por. G. Gierszewska, M. Romanowska, Analiza strategiczna przedsiębiorstwa, wyd. V, Warszawa 2017, s. 12-15; A. Sopińska, Wiedza jako strategiczny zasób przedsiębiorstwa. Analiza i pomiar kapitału intelektualnego przedsiębiorstwa, Warszawa 2010, s. 24-57; M. Romanowska, Planowanie strategiczne w przedsiębiorstwie, wyd. II, Warszawa 2009, s. 11-13; E. Stańczyk-Hugiet, Paradygmat relacji - czy to nowa jakość w zarządzaniu?, „Studia i Prace Kolegium Zarządzania i Finansów” 2012, nr 116, s. 164.

4 K. Obłój, op. cit., s. 24.

5 Analiza SWOT - nazwa jest akronimem od słów w języku angielskim określających element składowe analizy: Strengths (mocne strony), Weaknesses (słabe strony), Opportunities (szanse) i Threats (zagrożenia). Analiza SWOT polega na analizie mocnych i słabych stron organizacji oraz szans i zagrożeń związanych $\mathrm{z}$ otoczeniem.

${ }^{6}$ M. Romanowska, Planowanie strategiczne..., op. cit., s. 12. 
wzorca, który wyłania się z eksploatacji nowych opcji i powielania utrwalonych rozwiązań7. Strategia wyłania się wraz z upływem czasu i stanowi połączenie zamierzonych planów i wprowadzonych zmian ${ }^{8}$. Ważna jest umiejętność uczenia się oraz doskonalenia, gdyż tylko wtedy organizacja może osiągnąć sukces?.

Kolejna koncepcja to teoria pozycyjna, w której strategia powiązana jest $\mathrm{z}$ pozycją organizacji w otoczeniu konkurencyjnym ${ }^{10}$, co determinuje korzyści strategiczne, jakie mogą zostać przez nią osiągnięte ${ }^{11}$. Uwaga koncentruje się tu na tworzeniu strategii konkurencji, a nie wytyczaniu kierunków i tempa rozwoju organizacji. Strategia jest tworzona z perspektywy otoczenia konkurencyjnego, a nie zasobów wewnętrznych organizacji. Ta druga perspektywa charakteryzuje teorię zasobową, w której przyjmuje się, że sukces organizacji zależy od jakości zgromadzonych przez nią zasobów, szczególnie tych o charakterze niematerialnym ${ }^{12}$. Posiadane przez organizację zasoby są ważniejsze niż uwarunkowania sektorowe ${ }^{13}$. Maria Romanowska wskazuje jednak, że sukces organizacji nie zależy od posiadanych zasobów, ale od umiejętności zarządzania nimi. Autorka wskazuje cztery modelowe strategie zasobowe ${ }^{14}$ :

- „bogaty dyletant”, czyli organizacja, która posiada własne zasoby, ale nie umie nimi zarządzać;

- „władca skarbów”, czyli organizacja, która posiada własne zasoby oraz umiejętnie nimi zarządza;

7 K. Obłój, op. cit., s. 25.

8 E. Stańczyk-Hugiet, op. cit., s. 164.

9 M. Romanowska, Planowanie strategiczne... op. cit., s. 12.

10 Otoczenie konkurencyjne składa się ze wszystkich podmiotów, które mają z organizacją powiązania kooperacyjne lub konkurencyjne, czyli istniejący i potencjalni konkurenci, dostawcy, odbiorcy oraz producenci substytutów.

11 E. Stańczyk-Hugiet, op. cit., s. 164.

12 M. Romanowska, Planowanie strategiczne..., op. cit., s. 12-13.

13 K. Obłój, op. cit., s. 25.

14 M. Romanowska, Dostosowanie strategii przedsiębiorstwa do jego zasobów, [w:] Zarządzanie strategiczne. Ujęcie zasobowe, red. R. Krupski, Wałbrzych 2006, s. 93-96. 
- „chłopiec na posyłki”, czyli organizacja, która nie posiada własnych zasobów ani nie ma umiejętności korzystania i zarządzania zasobami cudzymi;

- „architekt biznesu”, czyli organizacja, która nie ma własnych zasobów, ale ma rozwinięte umiejętności korzystania i zarządzania zasobami cudzymi.

W opinii M. Romanowskiej, „można odnieść sukces, nie posiadając zasobów (»architekt biznesu«), ale nie można odnieść sukcesu, nie posiadając umiejętności zarządzania zasobami, nawet jeżeli te zasoby są obfite (»bogaty dyletant«)”15. Ważny jest dostęp do zasobów oraz umiejętność zarządzania nimi, a nie samo ich posiadanie. $Z$ tego względu strategia organizacji powinna być także postrzegana z perspektywy sieci ${ }^{16}$. Organizacje powinny utrzymywać i rozwijać relacje z innymi organizacjami i osobami, aby tworzyć, chronić i przechwytywać wytworzone wartości ${ }^{17}$. Relacje są ważnym źródłem przewagi konkurencyjnej w dynamicznie zmieniającym się świecie. Adam M. Brandenburger oraz Barry J. Nalebuff wyróżniają dwie strategie w zależności od zaangażowania organizacji w sieci relacji: strategię niezależności oraz uwikłania w sieć kooperacyjną ${ }^{18}$. Pierwsza $\mathrm{z}$ nich oznacza, że organizacja nie nawiązuje relacji z innymi organizacjami ani osobami. Druga natomiast, że organizacja nawiązuje różnorodne relacje i poprzez współpracę podnosi własną konkurencyjność w stosunku do organizacji, które nie są uczestnikami sieci.

Każda z przedstawionych teorii ma swoich zwolenników, krytyków, założenia, skrzynkę narzędziową oraz ograniczenia. Przedstawione teorie częściowo są sprzeczne, ale częściowo się uzupełniają. Uważam, że w praktyce bardzo ciężko wskazać tylko jedną teorię, zgodnie z którą organizacja postrzega swoją strategię. W organizacjach dominuje zazwyczaj jedno podejście, które łączone jest mniej lub bardziej świadomie z innymi (np.

15 Ibidem, s. 96.

16 E. Stańczyk-Hugiet, op. cit., s. 166.

17 D. Lewicka, A. Zakrzewska-Bielawska, Rola zaufania $w$ relacyjnej orientacji przedsiębiorstwa, [w:] Meandry teorii i praktyki zarządzania, red. G. Osbert-Pociecha, S. Nowosielski, Wrocław 2016, s. 109.

18 A.M. Brandenburger, B.J. Nalebuff, Co-Opetition, New York - London Toronto - Sydney - Auckland 1996. 
dominujące może być rozumienie strategii zgodnie $\mathrm{z}$ teorią ewolucyjną, ale $\mathrm{w}$ jej tworzeniu wykorzystuje się także elementy $\mathrm{z}$ teorii zasobowej). Uogólniając, można wskazać trzy podejścia do tworzenia strategii w organizacji. Pierwsze podejście - „od zewnątrz do wewnątrz” - oznacza, że strategia ukierunkowana jest rynkowo. To szanse i zagrożenia znajdujące się w otoczeniu organizacji determinują jej cele i strategie. W drugim podejściu - „od wewnątrz do zewnątrz” - przyjmuje się odwrotną perspektywę. Strategię determinują tu zasoby, które organizacja posiada lub ma do nich dostęp. W tym przypadku to mocne i słabe strony organizacji określają jej cele oraz strategie. Trzecie podejście integruje dwa poprzednie, gdyż strategia jest wypadkową posiadanych przez organizacje mocnych i słabych stron oraz szans i zagrożeń związanych z otoczeniem.

W tradycyjnym ujęciu strategia to efekt prac, które poprzedza analiza strategiczna oraz projektowanie strategii. Przygotowany dokument jest następnie przekazywany do realizacji, a zmiana strategii następuję dopiero w następnym okresie, który kolejny raz poprzedzają analizy strategiczne oraz projektowanie strategii. W nowoczesnym ujęciu strategia rozumiana jest jako ciągły i dynamiczny proces, który nigdy się nie kończy. Strategia to dynamiczny proces pokonywania trudności, jakie organizacja napotyka na drodze swojego rozwoju ${ }^{19}$.

\section{STRATEGIE ORGANIZACJI Z SEKTORÓW KULTURY}

W teorii zarządzania jednym z podstawowych pojęć jest organizacja, czyli „grupa ludzi, którzy współpracują ze sobą w sposób uporządkowany i skoordynowany, aby osiągnąć pewien zestaw celów"20. Stosując jeden z najprostszych podziałów, można wyróżnić organizacje działające dla zysku oraz organizacje niedziałające dla zysku. Celem organizacji działających dla zysku jest maksymalizacja wartości, a wypracowany zysk jest dzielony między właścicieli lub reinwestowany w dalszy rozwój organizacji, co ma zapewnić wzrost jej wartości w przyszłości. Natomiast celem organizacji niedziałających dla zysku jest realizacji misji oraz wytwarzanie produktów niekomercyjnych. Generowanie zysku nie jest celem, co nie oznacza, że nie

19 M. Romanowska, Planowanie strategiczne..., op. cit., s. 17, 19.

20 R.W. Griffin, Podstawy zarządzania organizacjami, wyd. II, tłum. M. Rusiński, Warszawa 2014, s. 5. 
może być on wypracowywany przez tego typu organizacje. Wygenerowany zysk nie jest dzielony między właścicieli, ale reinwestowany w rozwój organizacji. Heerad Sabeti zwraca jednak uwagę, że taki podział jest zbytnim uproszczeniem, gdyż współcześnie coraz trudniej przydzielić organizacje do określonego typu ${ }^{21}$. W obszarze kultury przykładów nie trzeba długo szukać. Warto zwrócić uwagę na opracowanie Towarzystwa Inicjatyw Twórczych $\mathrm{E}_{\ell}^{22}$ oraz książkę Kultura i rozwój. Analizy, rekomendacje, studia przypadków ${ }^{23}$. W obydwu pracach zwraca się uwagę na inicjatywy kulturalne / nieinstytucje kultury, które często nie wchodzą w sferę formalnej kultury, a nie można ich określić jako organizacji niedziałających dla zysku, przez co są trudne do uchwycenia i wymykają się wszelkim klasyfikacjom. Jednocześnie inicjatywny te mają wpływ na ład instytucjonalny w kulturze oraz rozwój społeczno-gospodarczy. Oznacza to, że powstają organizacje hybrydowe, które H. Sabeti nazywa przedsiębiorstwami nastawionym na korzyści niematerialne (for-benefit enterprises) ${ }^{24}$, a Justyna Szumniak-Samolej - przedsięwzięciami zbudowanymi wokół misji społecznej i/lub środowiskowej ${ }^{25}$. Organizacje hybrydowe łączą elementy charakterystyczne dla organizacji działających dla zysku (np. nacisk położony na efektywność działania) z elementami charakterystycznymi dla organizacji niedziałających dla zysku (np. koncentracja na realizacji misji). W sektorach kultury działają wszystkie trzy rodzaje organizacji - niedziałające dla zysku, hybrydowe

${ }^{21}$ H. Sabeti, Przedsiębiorstwo nastawione na korzyści niematerialne, „Harvard Business Review” 2012, nr 5, s. 67-74.

${ }^{22}$ M. Kubecka, M. Białek-Graczyk, Jaskółki. Nowe zjawiska w warszawskich instytucjach i nieinstytucjach kultury, 2016, http://nck.pl/media/attachments/317271/ Jask\%C3\%B3\%C5\%82ki.\%20Nowe\%20zjawiska\%20w\%20warszawskich\%20instytucjach\%20i\%20nieinstytucjach\%20kultury.pdf [dostęp: 2.02.17].

${ }_{23}$ Por. Kultura i rozwój. Analizy, rekomendacje, studia przypadku, red. J. Hausner, I. Jasińska, M. Lewicki, I. Stokfiszewski, Warszawa 2016.

${ }^{24}$ H. Sabeti, op. cit., s. 67-74.

25 J. Szumniak-Samolej, Innowacyjne przedsięwzięcia nawiąujące do idei społecznej odpowiedzialności biznesu na rynku polskim, [w:] Badania młodych naukowców $w$ dziedzinie nauk ekonomicznych a praktyka gospodarcza, red. M. Wolański, Warszawa 2015, s. 369-378; eadem, Polskie przedsiębiorstwa oparte na misji społecznej: modele biznesowe, motywacje, wyzwania, [w:] Wkład nauk ekonomicznych w budowę kapitału społecznego, red. M. Menkes, Warszawa 2016, s. 171-186. 
oraz działające dla zysku, choć trzeci typ jest najrzadziej spotykany. Opis strategii organizacji z sektorów kultury - jeśli wziąć pod uwagę powyższe uwarunkowania - jest interesującym tematem, który wymaga pogłębienia zarówno teoretycznego, jak i empirycznego.

Strategie organizacji z sektorów kultury stają się tematem rozważań coraz większej liczby naukowców i praktyków, ale w dalszym ciągu jest to obszar stosunkowo słabo rozwinięty. Mateusz Lewandowski zwraca uwagę na fakt, że metody i narzędzia zaczerpnięte $\mathrm{z}$ obszaru zarządzania strategicznego są coraz powszechniej stosowane w polskich instytucjach kultury $^{26}$. Instrumentarium zarządzania strategicznego wykorzystuje się także do opisu charakterystyki sektorów kultury (również w pracach naukowych), czego przykład stanowi praca Anny Wróblewskiej na temat sektora produkcji filmów fabularnych w Polsce ${ }^{27}$.

M. Lewandowski, wskazując obszary, w których prowadzane są badania dotyczące zarządzania strategicznego w polskich instytucjach kultury, wymienia kolejno: (1) tworzenie misji oraz proces zarządzania strategicznego $\mathrm{w}$ muzeach, (2) podejście do strategii i zarządzania strategicznego z perspektywy praktyków zarządzających instytucjami kultury, (3) strategie marketingowe w sektorze sztuki i filharmonii, a także (4) typologie strategii oraz charakterystykę procesu zarządzania strategicznego w instytucjach kultury ${ }^{28}$. Ostatni obszar jest tematem rozważań Lidii Varbanovej, która na podstawie gruntownej analizy literatury przedmiotu zaproponowała typologie różnych strategii organizacji w sektorach kultury, wyróżniając: główne strategie organizacji, strategie produktowo-rynkowe (programowo-rynkowe) oraz strategie konkurencji ${ }^{29}$ (tabela 1). Strategie ogólne określają kierunki rozwoju organizacji i dotyczą całej organizacji. Strategie produktowo-rynkowe (programowo-rynkowe) wskazują na ścieżki rozwoju pro-

26 M. Lewandowski, Czynniki utrudniające samodzielne opracowywanie planów strategicznych przez pracowników instytucji kultury, [w:] Zarządzanie w instytucjach kultury, red. Ł. Wróblewski, Warszawa 2014, s. 62.

27 A. Wróblewska, Kinematografia jako przemyst kultury. Uwarunkowania i tendencje rozwoju branży filmowej w Polsce, Warszawa 2013, s. 242-265.

28 M. Lewandowski, op. cit., s. 62-63.

29 L. Varbanova, Zarządzanie strategiczne w kulturze, tłum. T. Piwowarczyk, Warszawa 2015 [e-book]. 
duktów (programów) i rynków. Organizacja może koncentrować się na obecnych rynkach i produktach (programach), stosując strategie penetracji, lub może rozwijać nowe produkty (programy) i/lub rynki. Natomiast celem strategii konkurencji jest tworzenie, wzmacnianie i utrzymywanie przewagi konkurencyjnej, czyli osiągniecie przez organizacje lepszej pozycji w sektorze w porównaniu $z$ innymi podmiotami. Należy wskazać, że organizacje powinny posiadać i realizować każdy typ strategii oraz mogą realizować kilka strategii równocześnie. Przykładowo organizacja może realizować zarówno strategie innowacji, jak i strategie tworzenia sieci kontraktów (strategie ogólne) oraz strategie przywództwa kosztowego w jednym sektorze, strategie przywództwa jakościowego natomiast w innym (strategie konkurencji).

Tabela 1. Typologia strategii organizacji w sektorach kultury

\begin{tabular}{|c|c|c|}
\hline 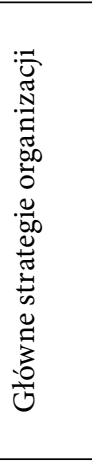 & $\begin{array}{l}\text { Strategie określające } \\
\text { kierunki, w jakich podążać } \\
\text { będzie organizacja }\end{array}$ & $\begin{array}{l}\text { strategia innowacji } \\
\text { strategia wydzielenia (outsourcingu) } \\
\text { strategia prywatyzacji } \\
\text { strategia budowania potencjału } \\
\text { strategia przetrwania } \\
\text { strategia likwidacji } \\
\text { strategia integracji } \\
\text { strategia partnerstwa } \\
\text { strategia klastrów kreatywnych } \\
\text { strategia koprodukcji } \\
\text { strategia tworzenia sieci kontraktów } \\
\text { strategia lobbingowa }\end{array}$ \\
\hline 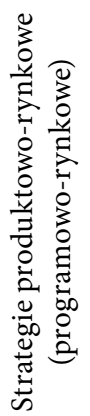 & $\begin{array}{l}\text { Strategie rozwoju, które } \\
\text { obarczone są różnym } \\
\text { ryzykiem }\end{array}$ & $\begin{array}{l}\text { strategia penetracji rynku } \\
\text { strategia rozwoju rynku } \\
\text { strategia rozwoju produktu (programu) } \\
\text { strategia dywersyfikacji }\end{array}$ \\
\hline
\end{tabular}




\begin{tabular}{|c|c|c|}
\hline 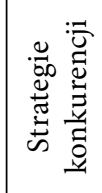 & $\begin{array}{l}\text { Strategie, które mają na } \\
\text { celu osiągniecie, wzmac- } \\
\text { nianie oraz utrzymanie } \\
\text { przewagi konkurencyjnej }\end{array}$ & $\begin{array}{l}\text { strategia przywództwa kosztowego } \\
\text { strategie dyferencjacji (zróżnicowania, } \\
\text { przywództwa jakościowego) } \\
\text { strategia koncentracji } \\
\text { strategia zintegrowana }\end{array}$ \\
\hline
\end{tabular}

Źródło: opracowanie własne na podstawie: L. Varbanova, Zarządzanie strategiczne w kulturze, tłum. T. Piwowarczyk, Warszawa 2015 [e-book].

W swojej pracy L. Varbanova definiuje także strategie organizacji z sektorów kultury jako: „system podejść, metod i narzędzi oceny i wyboru opcji prowadzących do realizowania misji i osiągnięcia długoterminowych celów w najskuteczniejszy sposób, przy uwzględnieniu wpływów zewnętrznych i wewnętrznych oraz zasobów i zdolności organizacji, jak również potencjału innowacyjności, przedsiębiorczości i kreatywności”30. W zaproponowanej definicji strategia postrzegana jest jako wypadkowa uwarunkowań zewnętrznych oraz mocnych i słabych stron organizacji. Posiadanie i realizowanie strategii jest kluczowe, aby osiągać założone cele oraz w pełni wykorzystać potencjał wewnętrzny organizacji.

Chis Bilton, badacz operujący pojęciem kreatywnej strategii, wyróżnia trzy podejścia do jej tworzenia: (1) model „heroiczny” ('heroic' model), (2) adhokrację (adhocracy) oraz (3) posthokrację (posthocracy). W „heroicznym" modelu kreatywnej strategii najważniejsze miejsce zajmuje lider. To on w oparciu o swoje doświadczenie, umiejętność analizy trendów rynkowych oraz kreatywność identyfikuje unikalną przewagę konkurencyjną oraz tworzy strategię. W adhokracji, zgodnie z założeniami teorii ewolucyjnej, strategia tworzona jest kolektywnie i przyrostowo, a przyszła strategia wyłania się z aktualnych działań ${ }^{31}$. W świecie chaosu oraz dominacji pozornie niepowiązanych ze sobą wydarzeń kluczowa jest umiejętność rozpoznawania słabych sygnałów oraz „niewidzialnych” prawidłowości, a porządek wyłania się z pozornie przypadkowych i niezorganizowanych interakcji ${ }^{32}$. Adhokracja

30 Ibidem.

31 C. Bilton, Management and Creativity. From Creative Industries to Creative Management, Oxford - Carlton 2007, s. 91 i n.

32 J. Hartley, J. Potts, S. Cunningham, T. Flew, M. Keane, J. Banks, Key Concepts in Creative Industries, Los Angeles - London - New Delhi - Singapore - Washington (DC) 2013, s. 28-29. 
w zarządzaniu strategicznym nie oznacza tylko prostego akceptowania chaosu i niepewności, ale odwołuje się do oddolnego (bottom-up) procesu tworzenia strategii, co oznacza, że wyłania się z działań i decyzji operacyjnych. Trzecim z podejść jest posthokracja, gdzie nieprzewidywalność otoczenia jest tak duża, że planowanie staje się niemożliwe. Podstawą podjęcia decyzji są emocje, ego oraz osobowość decydenta, a ich racjonalność określana jest expost ${ }^{33}$. Typy wskazane przez C. Biltona znajdują potwierdzenie w słowach Martyny Śliwy, która wskazuje, że w polskich instytucjach kultury podejście do strategii jest różnorodne: „od tradycyjnego, w myśl którego przywódca podejmuje większość decyzji i kieruje zespołem tak, aby realizował on jego wizję strategiczną, po styl oparty na budowaniu wizji strategicznej instytucji w dialogu z pracownikami i pozostawienie zespołowi znacznej wolności twórczej”" ${ }^{34}$. Podejście tradycyjne odpowiada „heroicznemu” modelowi kreatywnej strategii, natomiast drugie z nich - adhokracji. M. Śliwa wskazuje także, że nie istnieje jedna ogólna strategia realizowana przez wszystkie instytucje kultury w Polsce, gdyż każda z nich tworzy własną strategię, uwzględniając uwarunkowania otoczenia oraz swoje słabe i mocne strony ${ }^{35}$, co potwierdza wcześniejsze rozważania o różnych strategiach oraz jest spójne $z$ definicją strategii organizacji z sektorów kultury zaproponowaną przez L. Varbanovą.

Martyna Śliwa zaznacza ponadto, że zarządzający polskimi instytucjami kultury borykają się z dużą nieprzewidywalnością otoczenia ${ }^{36}$ oraz mają

${ }_{33}$ C. Bilton, op. cit., s. 91 i n.

${ }^{34}$ M. Śliwa, Stratedzy i strategie polskich instytucji kultury: podsumowanie, [w:] Strategie dla kultury. Kultura dla rozwoju. Zarzadzanie strategiczne instytucja kultury, red. M. Śliwa, Kraków 2011, s. 211.

35 Ibidem, s. 212.

36 Niepewność otoczenia jest stosunkowo szczegółowo opisana w literaturze przedmiotu. W związku z czym, biorąc pod uwagę także ograniczenia długości artykułu, zdecydowałem się pominąć opis tej sytuacji. Zainteresowanych czytelników zachęcam do zapoznania się z następującymi pracami: G. Bērziņš, Strategic Management in Creative Industry Organizations: Specifics in Strategic Decision Making, „Management of Organizations: Systematic Research” 2012, No. 62, s. 10-11; R.E. Caves, Creative Industries. Contracts Between Art and Commerce, Cambridge Massachusetts - London 2000, s. 2-3; D. Hesmondhalgh, The Cultural Industries, 
ograniczony wpływ na część decyzji podejmowanych w szeroko rozumianej sferze publicznej, które bezpośrednio dotyczą ich organizacji ${ }^{37}$. Organizacje działające w sferze publicznej, w tym także w sektorach kultury, mają narzuconą realizację misji publicznej, co wpływa na ich cele oraz strategie. Sprawia to, że cele organizacji niedziałających dla zysku są inne niż cele organizacji działających dla zysku, a przez to i sposoby ich osiągania będą się różnić. Dodatkowo, nierzadko władza na różnych szczeblach, pośrednio oraz bezpośrednio, wyraża swoje oczekiwania względem organizacji oraz sposobu realizacji misji publicznej. Otoczenie w sektorach kultury jest zatem złożone, a dla funkcjonowania organizacji w nich działających duże znaczenie mają czynniki polityczne. Władze centrale i samorządowe mają zasadniczy wpływ na kierunki polityki kulturalnej oraz ład instytucjonalny w sektorach kultury, przez co silnie oddziałują na cele organizacji. Nasuwa się więc pytanie, w jakim stopniu organizacje z sektorów kultury określają samodzielnie misje i cele? Jest to trudne do stwierdzenia, ale nie wydaje się jednak nadużyciem wskazanie, że organizacje z sektorów kultury są przynajmniej częściowo „ubezwłasnowolnione” w podejmowaniu decyzji strategicznych ${ }^{38}$ (np. ograniczenia prawne dotyczące prowadzenia działalności gospodarczej lub odmienne zamierzenia właścicieli). Kwestią utrudniającą tworzenie oraz realizowanie strategii jest także konieczność godzenia celów różnych grup interesariuszy (czyli osób indywidualnych, grup lub organizacji działających wewnątrz organizacji lub poza nią), których interesy są związane z zarządzaniem organizacją i mogą wpływać na jej działanie w sposób bezpośredni lub pośredni. Interesariusze wpływają na organizację, ale również są pod jej wpływem $^{39}$. W przypadku organizacji z sektorów kultury liczba interesariuszy

ed. III, Los Angeles - London - New Delhi - Singapore - Washington (DC) 2013, s. 26-28.

${ }^{37}$ M. Śliwa, op. cit., s. 212.

38 W tym miejscu warto zwrócić uwagę, że w przypadku niektórych organizacji działających dla zysku możliwość podejmowania decyzji strategicznych jest także ograniczona. Przykład stanowią spółki-córki, które są całkowicie zależne od spółek-matek. Strategie są tworzone przez spółkę-matkę, a zadaniem spółek-córek jest ich realizacja.

39 P. Wachowiak, Wrażliwość społeczna przedsiębiorstwa. Analiza i pomiar, Warszawa 2013, s. 46. 
jest o wiele większa niż w przypadku organizacji działających dla zysku ${ }^{40}$, a zaspokajanie ich potrzeb stanowi o wiele trudniejsze zadanie ${ }^{41}$. Różne grupy interesariuszy zgłaszają różne interesy, które często są sprzeczne, a zadaniem zarządzających organizacją jest takie przygotowanie i realizowanie strategii, aby zaspokoić aspiracje każdej z grup. Zarządzający muszą więc balansować pomiędzy różnymi interesami i wybierać rozwiązania kompromisowe, co również ogranicza swobodę podejmowania decyzji strategicznych.

\section{ZAMEK CIESZYN - STRATEGIA INNOWACYJNEJ (NIE)INSTYTUCJI KULTURY ${ }^{42}$}

Zamek Cieszyn powstał w 2005 roku $^{43}$ jako jednostka budżetowa miasta, ale od 2011 roku jest samorządową instytucją kultury prowadzoną wspólnie przez Miasto Cieszyn oraz Województwo Śląskie. Cel Zamku Cieszyn stanowi „rozwój innowacyjnej przedsiębiorczości poprzez wykorzystanie wzornictwa”, które jest postrzegane jako skuteczne narzędzie „podnoszenia konkurencyjności firm, instytucji, miast i regionów”44. Tak obrany cel sprawia, że Zamek Cieszyn koncentruje się na działaniu w trzech obszarach: designu, przedsiębiorczości oraz turystyki. Oferta w obszarze designu kierowana jest głównie do projektantów i obejmuje: warsztaty i szkolenia, doradztwo dla zakładających działalność gospodarczą oraz doradztwo/po-

40 Por. Ł. Gaweł, Zarządzanie strategiczne szlakiem dziedzictwa kulturalnego w świetle koncepcji stakeholders, „Turystyka Kulturowa” 2012, nr 10, s. 33-40.

${ }^{41}$ Por. W. Williams, D. Lewis, Strategic Management Tools and Public Sector Management, „Public Management Review” 2008, Vol. 10, No. 5, s. 655-660.

${ }^{42}$ Studium przypadku zostało przygotowane na podstawie wywiadów z pracownikami Zamku Cieszyn, udostępnionych przez nich materiałów oraz ogólnodostępnych informacji. Wywiady zostały przeprowadzone przez Patryka Dziurskiego (Szkoła Główna Handlowa w Warszawie, Instytut Zarządzania) i Mikołaja Lewickiego (Uniwersytet Warszawski, Instytut Socjologii) w okresie czerwiec-lipiec 2015 roku na potrzeby projektu badawczego pt. Kultura i rozwój finansowanego z Programu Ministra Kultury i Dziedzictwa Narodowego 2015 Obserwatorium Kultury.

${ }^{43}$ Do 2011 roku Zamek Cieszyn nosił nazwę: Śląski Zamek Sztuki i Przedsiębiorczości.

44 Projektujemy możliwości, http://www.zamekcieszyn.pl/pl/artykul/projektujemy-mozliwosci-199 [dostęp: 30.01.17]. 
moc przy wdrożeniach. W obszarze przedsiębiorczości oferta kierowana jest do biznesu i obejmuje: szkolenia prowadzone przez pracowników Zamku, szkolenia dostosowane do potrzeb klienta, prowadzone przez zewnętrznych ekspertów, doradztwo/pomoc przy wdrożeniach oraz organizowanie imprez firmowych. Dodatkowo obie grupy mają możliwość wynajmu powierzchni wystawienniczych i lokali. Zamek Cieszyn organizuje także wyjazdy na targi i festiwale designu. Ofertę w obszarze turystyki stanowi wynajem pokoi gościnnych, zwiedzanie wzgórza zamkowego, organizowanie warsztatów tradycyjnego i artystycznego rzemiosła oraz organizacja imprez ${ }^{45}$. Usługi oferowane przez Zamek Cieszyn są częściowo bezpłatne, częściowo natomiast świadczone na zasadach komercyjnych. Na budżet Zamku Cieszyn składa się dotacja z Urzędu Miasta i Województwa Śląskiego ( $1 / 3$ budżetu), finansowanie zewnętrzne (np. projekty unijne; $1 / 3$ budżetu) oraz przychody z działalności gospodarczej ( $1 / 3$ budżetu).

Zamek Cieszyn łączy w sobie tradycję i nowoczesność. Poprzez swoją nazwę i położenie na wzgórzu zamkowym bezpośrednio nawiązuje do tradycji oraz historii, pośrednio natomiast - poprzez ochronę i promocję tradycyjnego rzemiosła. Z drugiej strony, działalność Zamku Cieszyn jest zwrócona ku nowoczesnemu projektowaniu. Wytycza on kierunki rozwoju designu w Polsce poprzez promowanie projektowania usług, przestrzeni publicznej oraz zmian społecznych. Ewa Gołębiowska, dyrektor Zamku Cieszyn, zwraca uwagę, że „splecenie historii, tradycji, tożsamości z wzornictwem i nowoczesnymi technologiami” stanowi o sile Zamku ${ }^{46}$.

Zamek Cieszyn jest samorządową instytucją kultury, ale po zapoznaniu się z jego działalnością trudno go uznać za instytucję typową. Jedna z respondentek stwierdza: ,jesteśmy taką nietypową instytucją kultury” (respondentka 1). Ta sama osoba wskazuje, że razem z ekipą chcieliby zostać nazwani ,inspirującym miejscem”, a nie traktowani jak tradycyjna instytucja czy dom kultury. W materiałach prasowych można znaleźć informację, że pracownicy Zamku Cieszyn określają go mianem „firmy”, co oznacza,

${ }^{45}$ http://www.zamekcieszyn.pl/pl/artykul/oferta-200 [dostęp: 30.01.17].

46 E. Gołębiowska, Pomiędzy kultura i przedsiębiorczościa, tradycją i innowacyjnościa. Przykład: Zamek Cieszyn - centrum wzornictwa, instytucja kultury rozwijająca przedsiębiorczość, [w:] Strategie dla kultury..., op. cit., s. 157. 
że istnieje „określony cel, wspólnota działania, wizja, [...] strategia tego działania. [...] Mówimy o firmie niekoniecznie w sensie określania celu jako działalności gospodarczej nastawionej na zysk, ale skuteczności działania w konkretnie określonym celu" (respondentka 1). Inna z respondentek dodaje, że „my [pracownicy Zamku Cieszyn - przyp. P.D.] mamy zawsze gdzieś z tyłu głowy misję. Możemy czasem zrobić coś, co nie do końca jest opłacalne w sensie finansowym [...]; są działania, które dopiero za jakiś czas przynoszą pewne owoce i nie zawsze stricte finansowe, czasem zmianę mentalności, przygotowanie do wprowadzenia jakichś innych rozwiązań" (respondentka 2). Zamek Cieszyn łączy działalność służącą realizacji misji publicznej z działalnością gospodarczą, jest więc organizacją hybrydową, która spaja w sobie najlepsze elementy organizacji działających i niedziałających dla zysku.

Strategia w Zamku Cieszyn postrzegana jest jako dynamiczny proces pokonywania trudności na drodze rozwoju (ujęcie nowoczesne). Jego pracownicy wskazują na liczne problemy, które muszą być rozwiązywane, aby można było realizować projekty i się rozwijać. Zwraca się także uwagę na trudność w planowaniu długookresowym, szczególnie w aspekcie finansowym, co utrudnia działanie i zarządzanie całą organizacją. Ewa Gołębiowska jest bez wątpienia silnym liderem, ale - jak sama deklaruje w jednym $\mathrm{z}$ wywiadów ${ }^{47}$ - proces tworzenia, realizowania i nawet kontroli realizacji strategii odbywa się przy dużym udziale pracowników.

W Zamku Cieszyn strategia częściowo postrzega jest przez pryzmat teorii zasobowej, dlatego też podczas tworzenia strategii stosuje się podejście od wewnątrz do zewnątrz. Ważne są wszelkie rodzaje zasobów: zarówno materialne (zasoby finansowe i budynki), jak i niematerialne (wiedza i umiejętności, relacje, reputacja i wizerunek, silna marka oraz sprawny system zarządzania). Większa waga przypisywana jest jednak zasobom niematerialnym, szczególnie wiedzy i umiejętnościom oraz relacjom. Dyrektor Zamku Cieszyn wskazuje, że „instytucji jest potrzebny dobry, silny trzon, stały zespół”48. Potwierdza to także jedna z respondentek, mówiąc: „musimy mieć załogę, najważniejsze jest, żeby dobrać zespół i żeby ten zespół kształcić i związać" (respondentka 1).

47 Ibidem, s. 150.

48 Ibidem, s. 151. 
Ważnym niematerialnym zasobem Zamku Cieszyn są relacje, które były tworzone i wykorzystywane jeszcze przed jego powstaniem oraz w czasie jego działalności. W wywiadach podkreślono, że to dzięki pomocy i zaangażowaniu osób z Urzędu Miasta Cieszyn oraz Urzędu Marszałkowskiego możliwe było powstanie Zamku Cieszyn. Już po powstaniu natomiast intensywnie wykorzystywano różne relacje, aby pozyskać wiedzę i umiejętności potrzebne do realizacji przyjętej misji, co jest praktykowane do dziś (np. wykorzystywanie zewnętrznych ekspertów). Należy jednak zwrócić uwagę, że obecnie zespół Zamku Cieszyn posiada dużą wiedzę i umiejętności, które umożliwiają rozwój usług szkoleniowych i doradczych. Dodatkowo Zamek Cieszyn pełni rolę animatora współpracy, co oznacza, że jego działania umożliwiają tworzenie oraz wzmacnianie relacji między innymi osobami i organizacjami. Przykładowe inicjatywy tego typu to: Klub Przedsiębiorcy, Śląski Klaster Dizajnu oraz śniadania biznesowe. Duża sieciowość Zamku wykorzystywana jest także w codziennej działalności, aby pomóc przedsiębiorcom, projektantom oraz innym centrom designu, na co wskazuje jedna z respondentek: „zawsze można [do nas - przyp. P.D.] zadzwonić i się zapytać, gdzie są specjaliści do tego czy tamtego. Jak możemy pomóc, to przekazujemy telefony, namiary" (respondentka 1). Oznacza to, że Zamek Cieszyn realizuje strategię nazwaną przez Brandenburgera i Nalebuffa strategią uwikłania w sieć kooperacyjną lub strategię tworzenia sieci kontaktów z typologii zaproponowanej przez Varbanovą. Zamek Cieszyn tworzy różnorodne relacje, które wykorzystuje na drodze rozwoju oraz udostępnia innym partnerom.

Określenie strategii zasobowej Zamku Cieszyn jest trudnym zadaniem. Z jednej strony, posiada on własne zasoby (materialne, w postaci budynków oraz środków finansowych, oraz niematerialne, w postaci wiedzy, umiejętności i relacji), ale - z drugiej strony - z sukcesem korzysta $\mathrm{z}$ zasobów cudzych (głównie niematerialnych, w postaci wiedzy i umiejętności). Oznacza to, że Zamek Cieszyn posiada dobrze rozwiniętą umiejętność zarządzania zasobami nie tylko własnymi, ale także obcymi. Jego strategia zasobowa mieści się więc pomiędzy strategią „władcy skarbów” a strategią „architekta biznesu", ale w mojej opinii bliżej jest mu do pierwszej z wymienionych opcji.

Wydaje się także, że Zamek Cieszyn stosuje strategię innowacji, która w jego przypadku polega na poszerzaniu zakresu projektowania (nie tylko projektowanie produktów, ale także usług, przestrzeni publicznej oraz 
zmiany społecznej), co pozytywnie oddziałuje na wzrost efektywności. Wydaje się, że strategią produktowo-rynkową dla Zamku Cieszyn jest strategia rozwoju produktu. Oznacza to, że wprowadza on nowe produkty na dotychczasowych rynkach swojego działania.

Ostatnią kwestią, którą chciałbym poruszyć, jest wpływ interesariuszy na tworzenie oraz realizację strategii. Zamek Cieszyn musi radzić sobie z oczekiwaniami różnych interesariuszy. Przykładowo, sprzeczne interesy zgłaszają właściciele Zamku - władze wojewódzkie chcą zwiększyć obecność Zamku poza Śląskiem Cieszyńskim, natomiast władze miejsce oczekują większej obecności Zamku w Cieszynie ${ }^{49}$. Tworzenie oraz realizacja strategii przy tak sprzecznych oczekiwaniach jest niezwykle trudnym zadaniem, a do tego dochodzą jeszcze oczekiwania innych grup: środowiska designu, mieszkańców Cieszyna, przedsiębiorców, partnerów i pracowników, które są różne i mogą być wzajemnie sprzeczne. Strategia jest tworzona i realizowana w wyniku kompromisu, a nie na podstawie swobodnych decyzji pracowników Zamku Cieszyn, co potwierdza moje wcześniejsze uwagi.

\section{PODSUMOWANIE}

Powyższe rozważania skłaniają mnie do sformułowania dwóch wniosków. Po pierwsze, tworzenie oraz realizacja strategii są trudnymi zadaniami w organizacjach z sektorów kultury. Daleki byłbym jednak od stwierdzenia, że jest to proces trudniejszy niż w organizacjach działających dla zysku. Proces zarządzania strategicznego ma swoją specyfikę w każdym typie organizacji, a przed osobami tworzącymi oraz realizującymi strategię stoją odmienne wyzwania. Skłania mnie to do sformułowania drugiego wniosku, zgodnie z którym na proces tworzenia i realizacji strategii w organizacjach z sektorów kultury największy wpływ mają następujące czynniki: cele organizacji (odmienne od celów organizacji działających dla zysku), konieczność zarządzania sprzecznymi aktywnościami, takimi jak eksploracja i eksploatacja ${ }^{50}$,

${ }^{49}$ Por. P. Dziurski, Design jako źródło zmian społecznych. Studium przypadku Zamku Cieszyn, [w:] Kultura i rozwój. Analizy..., op. cit., s. 425-430.

${ }^{50}$ Kwestia zarządzania sprzecznymi aktywnościami, takimi jak eksploracja i eksploatacja, nie była poruszana w artykule, ale uważam, że jest to codzienne wyzwanie w sektorach kultury oraz kreatywnych, a przez to wpływa na proces tworzenia i realizacji strategii. Por. E.R.W. Knight, W.S. Harvey, Managing 
konieczność godzenia oczekiwań różnych grup interesariuszy, nieprzewidywalność otoczenia oraz czynniki polityczne.

Badania dotyczące strategii organizacji z sektorów kultury powinny być w dalszym ciągu prowadzone, gdyż ten obszar badawczy jest wciąż słabo odkryty. Uważam jednak, że w przyszłości powinny koncentrować się one nie tylko na strategii, ale na całym procesie zarządzania strategicznego, gdyż pozwoli to na uchwycenie pełnego obrazu rzeczywistości. Dodatkowo, wydaje się pożądane, żeby w przyszłych badaniach naukowcy wzięli pod uwagę wskazane przeze mnie uwarunkowania, aby potwierdzić ich słuszność, odrzucić je lub uzupełnić.

\section{Bibliografia}

Chris Bilton, Management and Creativity. From Creative Industries to Creative Management, Blackwell Publishing, Malden - Oxford - Carlton 2007.

Adam M. Brandenburger, Barry J. Nalebuff, Co-Opetition, Currency/Doubleday, New York - London - Toronto - Sydney - Auckland 1996.

Gundars Bērziņš, Strategic Management in Creative Industry Organizations:

Specifics in Strategic Decision Making, „Management of Organizations: Systematic Research" 2012, no. 62.

Richard E. Caves, Creative Industries. Contracts Between Art and Commerce, Harvard University Press, Cambridge (MA) - London 2000.

Łukasz Gaweł, Zarzadzanie strategiczne szlakiem dziedzictwa kulturalnego w świetle koncepcji stakeholders, „Turystyka Kulturowa” 2012, nr 10.

Grażyna Gierszewska, Maria Romanowska, Analiza strategiczna przedsiębiorstwa, wyd. V, PWE, Warszawa 2017.

Ricky W. Griffin, Podstawy zarządzania organizacjami, wyd. II, tłum. M. Rusiński, PWN, Warszawa 2014.

John Hartley, Jason Potts, Stuart Cunningham, Terry Flew, Michael Keane, John Banks, Key Concepts in Creative Industries, Sage, Los Angeles - London New Delhi - Singapore - Washington (DC) 2013.

Exploration and Exploitation Paradoxes in Creative Organizations, „Management Decision" 2015, Vol. 53, No. 4, s. 809-827; Y. Wu, S. Wu, Managing Ambidexterity in Creative Industries: A Survey, „Journal of Business Research” 2016, Vol. 69, No. 7, s. 2388-2396. 
David Hesmondhalgh, The Cultural Industries, wyd. III, Sage, Los Angeles - London - New Delhi - Singapore - Washington (DC) 2013.

Eric R. W. Knight, Will S. Harvey, Managing Exploration and Exploitation Paradoxes in Creative Organizations, „Management Decision” 2015, Vol. 53, No. 4.

Kultura i rozwój. Analizy, rekomendacje, studia przypadku, red. J. Hausner, I. Jasińska, M. Lewicki, I. Stokfiszewski, Krytyka Polityczna, Warszawa 2016. Mateusz Lewandowski, Czynniki utrudniajace samodzielne opracowywanie planów strategicznych przez pracowników instytucji kultury, [w:] Zarządzanie w instytucjach kultury, red. Ł. Wróblewski, CeDeWu.pl, Warszawa 2014.

Dagmara Lewicka, Agnieszka Zakrzewska-Bielawska, Rola zaufania w relacyjnej orientacji przedsiębiorstwa, [w:] Meandry teorii i praktyki zarządzania, red. G. Osbert-Pociecha, S. Nowosielski, Wydawnictwo UE we Wrocławiu, Wrocław 2016.

Krzystof Obłój, Strategia organizacji, wyd. III, PWE, Warszawa 2014.

Maria Romanowska, Dostosowanie strategii przedsiębiorstwa do jego zasobów, [w:] Zarzadzanie strategiczne. Ujęcie zasobowe, red. R. Krupski, Wałbrzyska Wyższa Szkoła Zarządzania i Przedsiębiorczości, Wałbrzych 2006.

Maria Romanowska, Planowanie strategiczne w przedsiębiorstwie, wyd. II, PWE, Warszawa 2009.

Heerad Sabeti, Przedsiębiorstwo nastawione na korzyści niematerialne, „Harvard Business Review" 2012, No. 5.

Agnieszka Sopińska, Wiedza jako strategiczny zasób przedsiębiorstwa. Analiza i pomiar kapitału intelektualnego przedsiębiorstwa, Oficyna wydawnicza SGH w Warszawie, Warszawa 2010.

Ewa Stańczyk-Hugiet, Paradygmat relacji - czy to nowa jakość w zarządzaniu?, „Studia i Prace Kolegium Zarządzania i Finansów” 2012, nr 116.

Strategie dla kultury. Kultura dla rozwoju. Zarządzanie strategiczne instytucja kultury, red. M. Śliwa, Małopolski Instytut Kultury, Kraków 2011.

Justyna Szumniak-Samolej, Innowacyjne przedsięwzięcia nawiązujace do idei społecznej odpowiedzialności biznesu na rynku polskim, [w]: Badania młodych naukowców $w$ dziedzinie nauk ekonomicznych a praktyka gospodarcza, red. M. Wolański, Oficyna Wydawnicza SGH w Warszawie, Warszawa 2015.

Justyna Szumniak-Samolej, Polskie przedsiębiorstwa oparte na misji społecznej: modele biznesowe, motywacje, wyzwania, [w:] Wkład nauk ekonomicznych w budowę kapitału społecznego, red. M. Menkes, Oficyna Wydawnicza SGH w Warszawie, Warszawa 2016. 
Lidia Varbanova, Zarzadzanie strategiczne $w$ kulturze, tłum. T. Piwowarczyk, Narodowe Centrum Kultury, Warszawa 2015.

Piotr Wachowiak, Wrażliwość społeczna przedsiębiorstwa. Analiza i pomiar, Oficyna Wydawnicza SGH, Warszawa 2013.

Wil Williams, Duncan Lewis, Strategic Management Tools and Public Sector Management, „Public Management Review” 2008, Vol. 10, No. 5.

Anna Wróblewska, Kinematografia jako przemysł kultury. Uwarunkowania i tendencje rozwoju branży filmowej w Polsce, Wydawnictwo Naukowe UKSW, Warszawa 2013.

Yuanyuan Wu, Shikui Wu, Managing Ambidexterity in Creative Industries: A Survey, „Journal of Business Research” 2016, Vol. 69, No. 7.

\section{Źródła internetowe}

http://www.zamekcieszyn.pl/pl/artykul/oferta-200.

Magdalena Kubecka, Marta Białek-Graczyk, Jaskółki. Nowe zjawiska w warszawskich instytucjach i nieinstytucjach kultury, 2016, http://nck.pl/media/attachments/317271/Jask\%C3\%B3\%C5\%82ki.\%20Nowe\%20zjawiska\%20w\%20 warszawskich\%20instytucjach\%20i\%20nieinstytucjach\%20kultury.pdf.

Projektujemy możliwości, http://www.zamekcieszyn.pl/pl/artykul/projektujemy -mozliwosci-199.

\section{Cultural (No)institutions' Strategies. Case Study of Zamek Cieszyn}

The aim of the article is to characterize the strategies of organizations in cultural industries, and as an exemplification one of cultural (no)institutions (Zamek Cieszyn) was chosen. Zamek Cieszyn is an unusual institution, because it combines the best elements from for-profit organizations with those from non-profit organizations. It is an example of good practise of managing an organisation in cultural industries. The author applies an appropriate methodology. The research method is a critical analysis of academic literature (a desk research) and a case study method. In the article, the author develops and supplements theoretical proposals, which are empirically verified in the case study. To sum up, creating and realizing strategies in organisations in cultural industries is a difficult task, since it is affected by the following factors: organizations' goals that are different from the goals in for-profit organizations, the necessity to manage conflicting activities; the 
need to reconcile different expectations of stakeholders; the unpredictability of the environment and influence of political factors.

Keywords: cultural industries, strategy, cultural institution, strategic management 